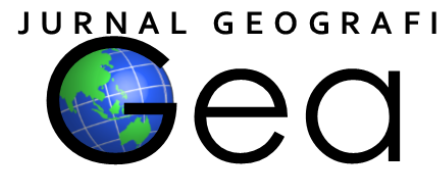

\title{
PENGARUH MODEL PEMBELAJARAN THINK TALK WRITE TERHADAP AKTIVITAS BELAJAR SISWA PADA MATA PELAJARAN GEOGRAFI KELAS X DI SMA NEGERI 2 MUARA ENIM TAHUN PELAJARAN 2017/2018
}

\author{
Yolanda Diliany Margarisya ${ }^{1}$, Murjainah $^{2}$, Bukman Lian $^{3}$ \\ 1,2,3 Universitas PGRI Palembang \\ ${ }^{1}$ Yolandamargarisya123@gmail.com, ${ }^{2}$ murjainah@gmail.com
}

\begin{abstract}
One part of the territory of the Republic of Indonesia that has been difficult to carry out the education process in accordance with the Standards of the Learning Process based on the 2013 curriculum, especially in backward regions of Lebak Regency, Banten. The condition of backward regions which still has obstacles to accessing and organizing education based on the 2013 Curriculum. Thus, the successful implementation of the 2013 Curriculum in backward regions would be a challenge to implement it appropriately and in accordance with established standards. This study aims to determine constraints implementation of geography learning process based on Curriculum 2013 at senior high school. This research uses qualitative approach with descriptive method. The principal participants in this study were Geography teachers at Senior High School who have implemented the Curriculum 2013 in backward region of Lebak Regency, Banten. Meanwhile, the participants of the base are learners and academic supervision. The research instruments are observation, interview, and document review.
\end{abstract}

Keywords: Obstacles, Curriculum 2013, Geography Learning.

\begin{abstract}
ABSTRAK
Model pembelajaran Think Talk Write adalah suatu model pembelajaran yang diawali bahan bacaan (menyimak, mengritisi, dan alternatif solusi), hasil bacaan dikomunikasikan dengan presentasi, diskusi, dan kemudian membuat laporan hasil presentasi. Tujuan penelitian ini untuk mengetahui pengaruh model pembelajaran Think Talk Write terhadap aktivitas belajar siswa pada mata pelajaran geografi kelas X di SMA Negeri 2 Muara Enim Tahun Pelajaran 2017/2018. Penelitian ini menggunakan penelitian kuantitatif dengan eksperimen desain yaitu preeksperimental designs (X-O). Dengan bentuk design One Shot Case Study. Populasi dalam penelitian ini yaitu seluruh kelas X IPS SMA Negeri 2 Muara Enim yang berjumlah 113 siswa dan sampel yang digunakan yaitu kelas X IPS B yang berjumlah 26 siswa. Teknik pengumpulan data yang digunakan yaitu teknik observasi, dan teknik dokumentasi. Dari analisis t-hitung = 338,651 dan t-tabel $=3,841$ dimana t-hitung $>t$-tabel $(338,651>3,841)$. Maka ada pengaruh yang signifikan dari penggunaan model pembelajaran Think Talk Write.
\end{abstract}

Kata kunci: Model Pembelajaran Think Talk Write, Aktivitas Belajar Siswa

\section{PENDAHULUAN}

Kemajuan teknologi dan informasi yang pesat membawa perubahan dalam kehidupan manusia. Hal ini berdampak terhadap perkembangan ilmu pengetahuan dan teknologi yang semakin cepat, perkembangan arus informasi yang semakin padat, dan tuntutan layanan profesional di berbagai sektor kehidupan. Peningkatan kualitas sumber daya manusia perlu disiapkan sejak dini untuk menghadapi tuntutan perubahan zaman salah satunya adalah melalui pendidikan. 
Aktivitas belajar merupakan salah satu aktivitas pendidikan yang dilakukan oleh siswa dalam kegiatan pembelajaran. Aktivitas belajar dapat terwujud apabila siswa terlibat belajar secara aktif. Kurikulum 2013 bertujuan untuk mendorong siswa untuk lebih aktif, kreatif dan inovatif dalam setiap pemecahan masalah yang mereka hadapi di sekolah. Undang-undang Nomor 14 Tahun 2005 tentang Guru dan Dosen Pasal (1) ayat (1) menyatakan, "Guru adalah pendidik profesionalisme dengan tugas utama mendidik, mengajar, membimbing, mengarahkan, melatih, menilai, dan mengevaluasi siswa pada jalur pendidikan formal, pendidikan dasar, dan pendidikan menengah". Dalam kurikulum 2013 seorang guru dituntut untuk secara profesional merancang pembelajaran afektif dan bermakna, mengorganisasikan pembelajaran, memilih pendekatan pembelajaran yang tepat, menentukan prosedur pembelajaran dan pembentukan kompetensi secara efektif, serta menetapkan kriteria keberhasilan. Dalam pemilihan pendekatan pembelajaran inovatif akan memunculkan kegembiraan belajar siswa. Hal ini dimaksud agar siswa lebih aktif dan kreatif dalam belajar geografi.

Berdasarkan observasi awal yang dilakukan di kelas X IPS di SMA Negeri 2 Muara Enim pada tanggal 30 januari 2018 menunjukkan bahwa proses belajar mengajar sudah terlaksana cukup baik, hanya saja aktivitas belajar siswa masih rendah yang disebabkan masih terdapat keterbatasan kemampuan siswa dalam memahami materi yang sudah dijelaskan yang mengakibatkan siswa kurang aktif dan aktivitas belajar rendah. Dari uraian yang telah dikemukakan, bahwa penelitian ini penting dilakukan untuk mengatasi permasalahan tersebut sehingga guru dapat menentukan model pembelajaran yang tepat, supaya memotivasi minat belajar siswa agar memahami suatu materi serta berperan aktif, dan pada akhirnya mampu meningkatkan aktivitas belajar siswa. Salah satu model pembelajaran yang dapat digunakan adalah model pembelajaran kooperatif tipe Think Talk Write.

Elida (2012) Model pembelajaran Think Talk Write dimulai dengan bagaimana siswa memikirkan penyelesaian suatu tugas atau masalah, kemudian diikuti dengan mengkomunikasikan hasil pemikirannya melalui forum diskusi, dan akhirnya melalui forum diskusi tersebut siswa dapat menuliskan kembali hasil pemikirannya. Siswa juga dituntut kreatif karena harus menuliskan hasil ide atau pemikirannya secara mandiri baru kemudian memecahkan masalah secara berkelompok. Siswa harus mampu mengikuti pembelajaran supaya apa yang diharapkan oleh guru dapat tercapai. Dengan model ini siswa menjadi lebih semangat, mandiri, dan terdorong untuk berfikir kritis. Model pembelajaran Think Talk Write diharapkan mampu mengubah aktivitas belajar siswa menjadi lebih aktif, karena model ini dapat melatih siswa berfikir dalam menyelesaikan sebuah permasalahan, aktif berdiskusi mencari solusi bersama teman kelompoknya dan kemudian menuliskan hasil diskusi kedalam bahasa sendiri.

Hasil penelitian Sari (2017) di SMA Negeri 1 Pekalongan menunjukkan rata-rata kemampuan menganalisis materi sejarah kelas eksperimen yang menggunakan model cooperative learning tipe Think Talk Write lebih tinggi dibandingkan kelas kontrol, dapat diartikan bahwa adanya pengaruh dalam penggunakan model pembelajaran cooperative learning tipe Think Talk Write kelas XI semester genap SMA Negeri 1 Pekalongan Tahun pelajaran 2016/2017. Dari hasil penelitian diatas menunjukkan bahwa model pembelajaran Think Talk Write cocok digunakan dalam proses pembelajaran sehingga siswa aktif dan bersemangat dalam proses pembelajaran. Oleh karena itu peneliti mengharapkan model pembelajaran Think Talk Write ini ada pengaruhnya terhadap aktivitas belajar siswa. Dengan model ini siswa menjadi lebih semangat, mandiri, dan terdorong untuk berfikir kritis. Model pembelajaran Think Talk Write diharapkan mampu mengubah aktivitas belajar siswa menjadi lebih aktif. Karena model ini dapat melatih siswa berfikir dalam menyelesaikan sebuah permasalahan, aktif berdiskusi mencari solusi bersama teman kelompoknya dan kemudian menuliskan hasil diskusi kedalam bahasa sendiri.

Selanjutnya, Widiastika (2017) di SMP Negeri Kubu Karangasem menunjukkan motivasi dan prestasi belajar pada siswa yang 
mengikuti pembelajaran dengan model kooperatif tipe Think Talk Write lebih baik dibandingkan dengan motivasi dan prestasi belajar pada siswa yang mengikuti pembelajaran dengan model konvensional. Oleh karena itu, penelitian ini bertujuan untuk mengetahui ada atau tidak pengaruh model pembelajaran Think Talk Write terhadap aktivitas belajar siswa pada mata pelajaran geografi kelas X di SMA Negeri 2 Muara Enim Tahun Pelajaran 2017/2018.

Salah satu model pembelajaran yang diharapkan dapat meningkatkan aktivitas belajar siswa adalah model pembelajaran Think Talk Write. Model pembelajaran Think Talk Write adalah sebuah pembelajaran yang dimulai dengan berpikir melalui bahan bacaan (menyimak, mengritisi, dan alternatif solusi), hasil bacaan dikomunikasikan dengan presentasi, diskusi, dan kemudian membuat laporan hasil presentasi (Siswanto, 2016:107). Dalam model pembelajaran Think Talk Write sebelum pelajaran dimulai siswa diberikan: (1) LKS yang berisi masalah; (2) Siswa membaca masalah yang ada dalam LKS dan membuat catatan kecil secara individu tentang apa yang mereka ketahui dan yang tidak diketahui; (3) Siswa berdiskusi dengan teman dalam kelompok untuk membahas isi catatan yang dibuatnya; (4) Dari hasil diskusi, siswa secara individu merumuskan pengetahuan berupa jawaban atas soal (berisi landasan keterkaitan konsep, metode, dan solusi) dalam bentuk tulisan (Write) dengan bahasa sendiri; (5) Perwakilan kelompok menyajikan hasil diskusi kelompok, sedangkan kelompok lain diminta memberikan tanggapan; (6) Kegiatan akhir pembelajaran adalah membuat refleksi dan kesimpulan atas materi yang dipelajari.

Menurut Daryanto (2013:2), belajar ialah suatu proses usaha yang dilakukan seseorang untuk memperoleh suatu perubahan tingkah laku yang baru secara keseluruhan, sebagai hasil pengalamannya sendiri dalam interaksi dan lingkungannya. Aktivitas yang bersifat psikologis, yaitu aktivitas yang merupakan proses mental, misalnya aktivitas berfikir, memahami, menyimpulkan, menyimak, menelaah, membandingkan, membedakan, mengungkapkan, menganalisis, dan sebagainya. Sedangkan aktivitas fisiologis yaitu aktivitas yang merupakan proses penerapan atau praktik, membuat karya (produk), apresiasi dan sebagainya. Hamalik (2013:171) mengungkapkan bahwa aktivitas belajar adalah aktivitas yang bersifat fisik maupun mental, dalam proses belajar kedua aktivitas itu harus saling berkaitan.

Dierich dalam Hamalik (2013), menyatakan aktivitas belajar dibagi ke dalam delapan kelompok, yaitu sebagai berikut: a) Kegiatan-kegiatan visual; b) Kegiatankegiatan lisan (oral); c) Kegiatan-kegiatan mendengarkan; d) Kegiatan-kegiatan menulis; e) Kegiatan-kegiatan menggambar; f) Kegiatan-kegiatan metrik; g) Kegiatankegiatan mental; h) Kegiatan-kegiatan emosional. Kemudian, Dierich dalam Hamalik (2013) menyatakan aktivitas belajar dibagi ke dalam delapan kelompok, yaitu; a. Kegiatankegiatan visual Membaca, melihat gambargambar, mengamati eksperimen, demonstrasi, pameran, dan mengamati orang lain bekerja atau bermain. b. Kegiatan-kegiatan lisan (oral) mengemukakan suatu fakta atau prinsip, menghubungkan suatu kejadian, mengajukan pertanyaan, memberi saran, mengemukakan pendapat, wawancara, diskusi, dan interupsi. c. kegiatan-kegiatan mendengarkan penyajian bahan, mendengarkan percakapan atau diskusi kelompok, mendengarkan suatu permainan, mendengarkan radio. d. kegiatan-kegiatan menulis cerita, menulis laporan, memeriksa karangan, bahan-bahan kopi, membuat rangkuman, mengerjakan tes, dan mengisi angket. e. kegiatan-kegiatan menggambar, membuat grafik, chart, diagram peta, dan pola. f. kegiatan-kegiatan metrik metrik, melakukan percobaan, memilih alat-alat, melaksanaan pameran, membuat model, menyelenggarakan permainan, menari, dan berkebun. g. kegiatanmental, merenungkan, mengingat, memecahkan masalah, menganalisis, faktorfaktor, melihat, hubungan-hubungan, dan membuat keputusan. h. kegiatan-kegiatan emosional, minat, membedakan, berani, tenang, dan lain-lain. Kegiatan-kegiatan dalam kelompok ini terdapat dalam semua jenis kegiatan dan overlap satu sama lain.

\section{METODE PENELITIAN}

Penelitian ini merupakan penelitian deskriptif kuantitatif dengan metode eksperimen. Desain eksperimen yang 


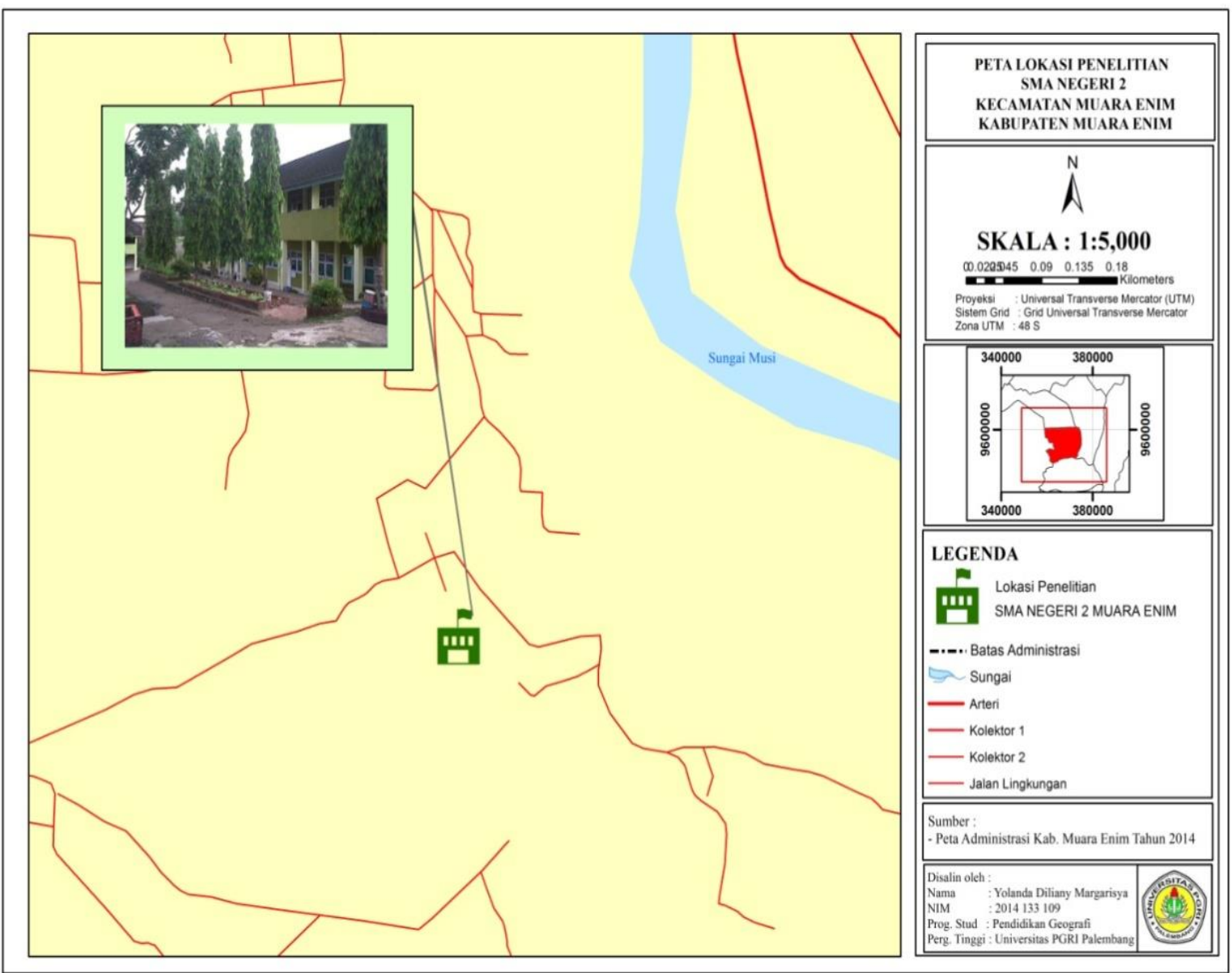

Sumber: Olah data 2018

Gambar 1. Peta Lokasi SMA Negeri 2 Muara Enim

Tabel 1. Kisi-Kisi Lembar Observasi Siswa

No Indikator

Aktivitas yang diamati
1. Aktivitas Visual a) Memperhatikan apa yang disampaikan guru
b) Mengamati kegiatan presentasi
c) Memperhatikan apa yang disampaikan teman pada saat diskusi
d) Membaca buku

2. Aktivitas Lisan

a) Aktif dalam diskusi kelompok

b) Mampu mengemukakan pendapat dalam kelompok

c) Aktif bertanya

d) Mampu menjawab pertanyaan
3. Aktivitas
a) Mendengarkan dari penjelasan/informasi guru
Mendengarkan
b) Mendengarkan pendapat dari kelompok lain
4. Aktivitas Menulis
a) Membuat catatan kecil secara individu dalam kelompok
5. Aktivitas
b) Membuat kesimpulan presentasi dari kelompok lain
Menggambar
a) Menggambar siklus hidrologi secara keseluruhan
b) Menggambar tiga siklus hidrologi:
1. Siklus panjang
2. Siklus sedang
3. Siklus pendek 

6. Aktivitas Metrik
a) Melakukan presentasi
7. Aktivitas Mental
a) Bekerja sama dengan kelompok
b) Memecahkan masalah dalam kelompok
c) Membuat kesimpulan dalam diskusi kelompok atau membuat catatan kecil dalam kelompok
8. Aktivitas
a) Berani dalam mengemukakan pendapat diskusi
Emosional
b) Bersemangat dalam proses belajar mengajar
c) aktif dalam kegiatan diskusi

\section{Sumber: Peneliti 2018}

digunakan dalam penelitian ini yaitu preeksperimental designs (X-O). Dikatakan preeksperimental designs, karena desain ini belum merupakan eksperimen sungguh-sungguh. Karena masih terdapat variabel luar yang ikut berpengaruh terhadap terbentuknya variabel dependen. Jadi hasil eksperimen yang merupakan dependen itu bukan semata-mata dipengaruhi oleh variabel independen (Arikunto, 2006). Bentuk design yang digunakan penelitian ini yaitu One-Shot Case Study. Adapun, lokasi penelitian ini adalah SMA Negeri 2 Muara Enim. Peta lokasi penelitian dapat dilihat pada gambar 1 .

Dalam penelitian ini yang menjadi populasi adalah seluruh kelas X IPS SMA Negeri 2 Muara Enim yang berjumlah 113. Sedangkan sampel dalam penelitian ini yaitu kelas X IPS B yang berjumlah 26 yang terdiri dari 7 laki-laki dan 19 perempuan. Teknik pengumpulan data dalam penelitian ini adalah observasi dan dokumentasi. Observasi adalah alat pengumpulan data yang dilakukan dengan cara mengamati dan mencatat secara sistematik gejala-gejala yang diselidiki (Narbuko, 2008). Dalam penelitian ini observasi digunakan untuk melakukan pengamatan secara langsung di lapangan agar dapat mengetahui keadaan yang berlangsung pada proses pembelajaran di kelas. Adapun kisi-kisi lembar observasi aktivitas belajar siswa dalam pembelajaran dapat dilihat di tabel 1. Kemudian, kriteria penilaian instrumen aktivitas belajar siswa menggunakan Skala Guttman. Skala pengukuran dengan tipe ini akan didapat jawaban yang tegas, yaitu "ya-tidak". Dokumentasi adalah menyelidiki benda-benda tertulis seperti buku-buku, majalah, dokumen, peraturan-peraturan, notulen rapat, catatan harian dan sebagainya (Arikunto, 2010:201). Dokumentasi digunakan untuk mencari data mengenai hal-hal atau variabel berupa catatan atau dokumen yang dipelajari untuk memperoleh data dalam penelitian. Adapun, kisi-kisi observasi dapat dilihat pada tabel 1 .

Analisis data dalam penelitian ini menggunakan statistik non parametris yaitu uji Chi Square atau Chi Kuadrat $\left(\chi^{2}\right)$ satu sampel adalah teknik statistik yang digunakan untuk menguji hipotesis bila dalam populasi terdiri atas dua atau lebih kelas dimana data berbentuk nominal dan sampelnya besar $>25$ (Sugiyono, 2016:107). Adapun rumus yang digunakan sebagai berikut :

$$
\chi^{2}=\sum_{i=1}^{k}\left(\frac{f 0-f h}{f h}\right)^{2}
$$

$$
\begin{aligned}
& \text { Keterangan: } \\
& \chi^{2}=\text { Chi Kuadrat } \\
& \text { fo }=\text { frekuensi yang diobservasi } \\
& \text { fh }=\text { frekuensi yang diharapkan }
\end{aligned}
$$

\section{HASIL DAN PEMBAHASAN}

Agar dapat mengetahui aktivitas belajar siswa dengan menggunakan model pembelajaran Thin Talk Write, peneliti melakukana observasi siswa saat pembelajaran berlangsung. Adapun hasil observasi mengenai aktivitas belajar siswa dapat dilihat pada gambar 2 .

Analisis data dalam penelitian ini tidak menggunakan uji prasyarat dan uji hipotetis, karena uji prasyarat dan uji hipotetis termasuk uji statistik parametris, sedangkan dalam penelitian ini menggunakan uji statistik non parametris (Uji Chi-kuadrat) jika dalam penelitian ini menggunakan uji prasyarat dan uji hipotesis maka data tersebut tidak homogen dan tidak normal. Oleh kerena itu dalam penelitian ini menggunakan Uji Chi-kuadrat. Berikut pengujian menggunakan uji ChiKuadrat. Berdasarkan $\mathrm{dk}=1$ dan taraf 
kesalahan yang ditetapkan 5\% maka harga Chi kuadrat tabel $=3,841$. Hasil perhitungan penelitian ini menggunakan perhitungan microsoft office excel dan disajikan dalam bentuk tabel uji Chi-kuadrat kelas X IPS B. Hasil Uji Chi Kuadrat dapat dilihat pada tabel 2.

Dari hasil perhitungan di dapat t-hitung sebesar 338,651. Maka t-hitung > t-tabel yaitu $338,651>3,841$. Maka Ho ditolak dan Ha diterima. Jadi, hipotesis dalam penelitian yang menyatakan bahwa ada pengaruh yang positif dari penggunaan model pembelajaran Think Talk Write tehadap aktivitas belajar siswa pada mata pelajaran geografi kelas $\mathrm{X}$ di SMA Negeri 2 Muara Enim dapat diterima kebenarannya. Berdasarkan tabel diatas, data perhitungan menggunakan uji Chi-kuadrat dapat disimpulkan bahwa penggunaan model pembelajaran Think Talk Write berpengaruh signifikan terhadap aktivitas belajar siswa pada mata pelajaran geografi kelas X di SMA Negeri 2 Muara Enim.

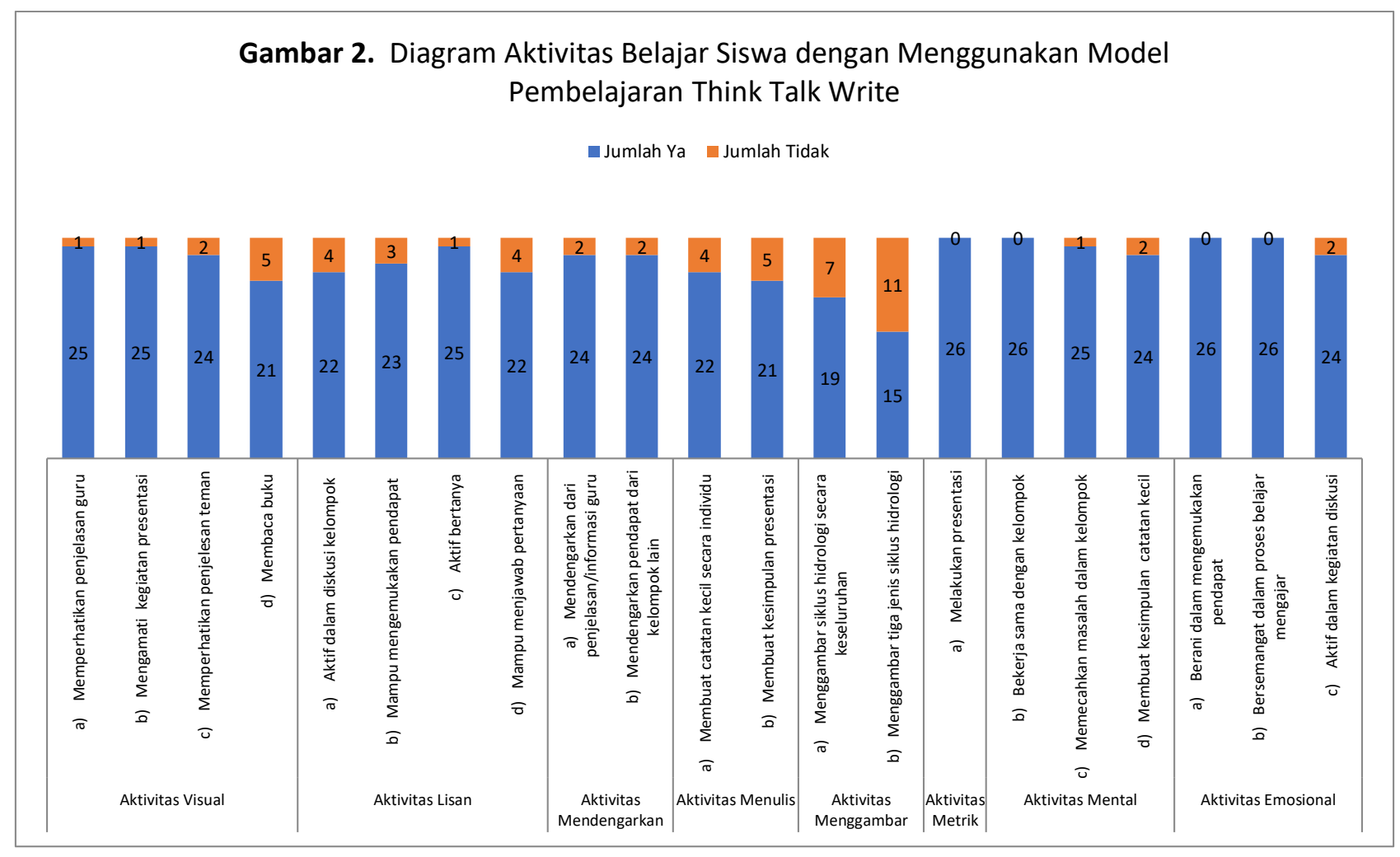

Tabel 2. Uji Chi-Kuadrat Kelas X.IPS B

\begin{tabular}{cccccc}
\hline $\begin{array}{c}\text { Alternatif } \\
\text { pilihan }\end{array}$ & Fo & Fh & Fo - Fh & $(\text { Fo }- \text { Fh })^{2}$ & $\frac{(\text { Fh }- \text { Fo })^{2}}{\text { Fh }}$ \\
\hline Ya & 489 & 273 & 216 & 46656 & 170,901 \\
\hline Tidak & 57 & 273 & -214 & 45796 & 167,75 \\
\hline Jumlah & $\mathbf{5 4 8}$ & $\mathbf{5 4 6}$ & $\mathbf{2}$ & $\mathbf{9 2 4 5 2}$ & $\mathbf{3 3 8 , 6 5 1}$ \\
\hline & & & & & Sumber: Olah data 2018
\end{tabular}


Penelitian ini dilakukan sebanyak 3 kali pertemuan dengan alokasi waktu 3 x 40 menit menggunakan model pembelajaran Think Talk Write dengan materi pokok hidrologi. Populasi dalam penelitian ini adalah seluruh siswa kelas X IPS SMA Negeri 2 Muara Enim. Sedangkan, sampel terdiri dari satu kelas yaitu kelas X IPS B yang berjumlah 26 siswa.

Penggunaan model pembelajaran Think Talk Write dapat memberikan peran yang baik terhadap aktivitas belajar siswa. Model pembelajaran Think Talk Write yang dimaksud yaitu berupa model pembelajaran yang berbentuk kelompok. Pada kegiatan proses pembelajaran siswa diberikan penjelasan mengenai materi hidrologi. Kemudian, siswa diberi kesempatan untuk aktif menjawab pertanyaan, dan bertanya untuk materi yang belum dimengerti.

Hasil lembar observasi siswa, ditinjau dari jawaban pada setiap item pertanyaan terkait dengan delapan indikator aktivitas belajar siswa secara keseluruhan didapat skor responden yang menjawab iya dan tidak berjumlah 546 item aktivitas belajar siswa. Diantara responden yang menjawab iya berjumlah 489 item aktivitas belajar siswa terdapat 26 siswa berani dalam mengemukakan pendapat, bersemangat dalam proses belajar mengajar, bekerja sama dalam kelompok, dan melakukan presentasi; 25 siswa memperhatikan penjelasan yang disampaikan oleh guru, mengamati kegiatan presentasi, aktif bertanya, dan mampu memecahkan masalah dalam kelompok; 24 siswa memperhatikan penjelasan yang disampaikan oleh teman pada saat diskusi, mendengarkan pendapat dari kelompok lain, mendengarkan dari penjelasan/informasi guru, membuat kesimpulan dalam diskusi kelompok, dan aktif dalam kegiatan diskusi; 23 siswa mampu mengemukakan pendapat dalam kelompok; 22 siswa aktif bertanya, mampu menjawab pertanyaan, dan membuat catatan kecil secara individu; 21 siswa membaca buku dan dapat membuat kesimpulan presentasi dari kelompok lain; 19 siswa dapat menggambar siklus hidrologi secara keseluruhan. Namun, setelah ditugaskan membuat gambar siklus hidrologi berdasarkan jenisnya terdapat 15 siswa yang dapat menggambar tiga macam siklus hidrologi (siklus pendek, sedang dan panjang), hal ini disebabkan karena saat melaksanakan pembelajaran dengan menggunakan model pembelajaran Think Talk Write sebagian siswa kurang memiliki kemampuan untuk memahami materi siklus hidrologi. Sebab setiap siswa memiliki kemampuan yang beragam sehingga memungkinkan siswa kurang memahami materi secara keseluruhan. Namun, ini juga perlu dikaji lebih lanjut mengenai motivasi maupun minat belajar siswa dengan menggunakan model pembelajaran Think Talk Write.

Bila dilihat kelebihan maupun
kelemahan model pembelajaran TTW, Siswanto (2016) mengungkapkan bahwa kelebihan model ini diantaranya, mempertajam seluruh keterampilan berpikir kritis; mengembangkan pemecahan yang bermakna dalam rangka memahami materi ajar; dengan memberikan soal dapat mengembangkan keterampilan berfikir kritis dan kreatif siswa; dengan berinteraksi dan berdiskusi dengan kelompok akan melibatkan siswa secara aktif dalam belajar; membiasakan siswa berpikir dan berkomunikasi dengan teman, guru, dan bahkan dengan diri mereka sendiri; memberikan pembelajaran ketergantungan secara positif; suasana menjadi rileks sehingga terjalinnya hubungan persahabatan antara siswa dan guru; dan adanya keterampilan menjalin hubungan interpersonal yang berupa keterampilan sosial berupa: tenggang rasa, bersikap sopan terhadap teman, mengkritik ide orang lain secara benar, berani mempertahankan pikiran dengan logis, dan berbagai keterampilan lain yang bermanfaat untuk menjalin hubungan antar individu.

Kelemahan model pembelajaran Think Talk Write diantaranya, ketika siswa bekerja dalam kelompok itu mudah kehilangan kemampuan dan kepercayaan, karena didominasi oleh siswa yang mampu; guru harus benar-benar menyiapkan semua media dengan matang agar dalam menerapkan model pembelajaran Think Talk Write tidak mengalami kesulitan; dengan keleluasaan pembelajaran maka apabila keleluasaan itu tidak optimal maka tujuan dari apa yang dipelajari tidak dapat tercapai; apabila guru kurang jeli, dalam memberikan penilaian 
individu akan sulit; dibutuhkan fasilitas yang cukup memadai untuk pelaksanaan.

Jadi, berdasarkan aktivitas belajar siswa dengan menggunakan model TTW dengan merujuk pada kelebihan dan kelemahan tersebut setelah eksperimen model pembelajara ini diberikan perlakuan kepada siswa terlihat bahwa siswa berani mengungkapkan pendapat, siswa dapat bertukar informasi antar kelompok/siswa; siswa menjadi lebih aktif; siswa dapat menambah pengetahuannya dari kelompok lain dengan cara diskusi kelompok; melatih siswa berfikir, berbicara dan membuat catatan sendiri. Namun sebaliknya, terdapat sebagian siswa sulit untuk membentuk kelompok dan dapat bekerja sama dengan baik, ketika menyampaikan pendapatnya siswa kurang percaya diri, dan memerlukan waktu yang lama pada saat diskusi kelompok.

Kemudian, dilihat dari hasil perhitungan aktivitas belajar siswa dengan menggunakan chi-kuadrat menunjukkan bahwa terdapat responden yang menjawab iya berjumlah 489 item aktivitas belajar siswa dan yang menjawab tidak berjumlah 57 item aktivitas belajar. Kemudian, didapat skor akhir sebesar 338,651 dengan derajat kebebasan atau t-tabel $=3.841$. Sehingga menunjukkan hasil t-hitung sebesar 338,651 dan t-tabel sebesar 3.841, jika t-hitung > t-tabel maka kriteria hipotesis dalam penelitian ini adalah Ho ditolak dan $\mathrm{Ha}$ diterima. Hal ini berarti terdapat pengaruh yang signifikan dari penggunaan model pembelajaran Think Talk Write dalam pembelajran geografi pada pokok pembahasan hidrologi.

Hal ini sejalan dengan hasil penelitian yang dilakukan oleh Rosyadi (2017) dengan judul "Pengaruh penggunaan model pembelajaran cooperative learning tipe Think Talk Write terhadap hasil belajar IPS TERPADU siswa kelas VIII semester genap SMP PGRI 4 Labuhan Ratu. Berdasarkan hasil penelitiannya menunjukkan bahwa model pembelajaran cooperative learning tipe Think Talk Write dalam proses pembelajaran dapat meningkatkan hasil belajar IPS terpadu siswa kelas VIII SMP PGRI 4 Labuhan Ratu. Dimana siswa yang dinyatakan tuntas belajar dengan $\mathrm{KKM} \geq$ setelah diberikan treatment sebanyak 26 siswa atau $76,47 \%$ dan siswa yang dinyatakan belum tuntas sebanyak 8 siswa atau $26,53 \%$ maka proses belajar yang dilaksanakan dinyatakan berhasil dalam meningkatkan hasil belajar ekonomi siswa. Jadi, dapat disimpulkan bahwa penggunaan model pembelajran Think Talk Write berpengaruh signifikan terhadap aktivitas belajar siswa pada mata pelajaran geografi kelas X pada pokok bahasan hidrologi.

\section{SIMPULAN}

Berdasarkan hasil observasi yang dilakukan peneliti dalam proses belajar mengajar; 1) siswa dapat bertukar informasi antar kelompok/siswa; 2) siswa menjadi lebih aktif; 3) siswa dapat menambah pengetahuannya dari kelompok lain dengan cara diskusi kelompok; 4) melatih siswa berfikir, berbicara dan membuat catatan sendiri. Dari analisis data yang menggunakan rumus Uji Chi-kuadrat, menunjukkan bahwa hasil t-hitung sebesar 338,651 dan t-tabel sebesar 3.841, jika t-hitung $>$ t-tabel maka kriteria hipotesis dalam penelitian ini adalah Ho ditolak dan $\mathrm{Ha}$ diterima. Jadi, dapat disimpulkan ada pengaruh yang signifikan dari penggunaan model pembelajaran Think Talk Write terhadap aktivitas belajar siswa pada mata pelajaran geografi kelas X di SMA Negeri 2 Muara Enim pada pokok bahasan hidrologi.

\section{REKOMENDASI}

Berdasarkan kesimpulan yang telah dipaparkan sebelumnya maka penulis mencoba memberikan beberapa hal sebagai bahan rekomendasi dalam kegiatan belajar dengan dilakukannya pengamatan sebaiknya dilakukan satu orang observer dalam 1 kelompok belajar dan juga diperlukan pembelajaran berkelanjutan tidak hanya beberapa kali pertemuan. Perlunya mengkaji lebih lanjut kemampuan siswa dalam memahami materi pelajaran dengan merujuk pada motivasi dan minat siswa dalam belajar dan perlunya bagi pendidik memberikan motivasi awal kepada siswa sebelum kegiatan belajar mengajar berlangsung.

\section{DAFTAR PUSTAKA}

Arikunto. (2006). Prosedur Penelitian. Jakarta: PT Rineka Cipta. 
Arikunto. (2010). Prosedur Penelitian Suatu Pendekatan Praktik. Jakarta: Reneka Cipta.

Daryanto. (2013). Belajar dan Mengajar. Bandung: CV. Yrama Widya.

Elida, Nunun. (2012). Meningkatkan kemampuan komunikasi matematik siswa sekolah menengah pertama melalui pembelajaran Think Talk Write. (pp. 181). Bandung: STKIP Siliwangi.

Hamalik, Oemar. (2013). Proses Belajar Mengajar. Jakarta: PT Bumi Aksara.

Narbuko. (2008). Metodelogi Penelitian. Jakarta: PT Bumi Aksara.

Rosyadi, Royan. (2017). Pengaruh Penggunaan Model Pembelajaran Cooperative Learning Tipe Think Talk Write Terhadap Hasil Belajar IPS Terpadu Siswa Kelas VIII Semester Genap SMP PGRI 4 Labuhan Ratu. JPGMI Universitas Nahdatul Ulama Vol.3 No.1.
Sari, E.N. (2017). Pengaruh Model Cooperative Learning Tipe Think Talk Write Terhadap Kemampuan Siswa dalam Menganalisis Materi Sejarah, Jurnal Swarnadwipa Universitas Muhamadiyah Metro Vol.1 No.1.

Siswanto, Wahyudi \& Dewi Ariani. (2016). Model Pembelajaran Menulis Cerita. Bandung: PT Refika Aditama.

Sugiyono. (2015). Metode Penelitian Pendidika. Bandung: Alfabeta.

Widiastika,I Gede. (2017). Model Pembelajaran Tipe Think Talk Write dan Pengaruhnya Terhadap Motivasi dan Prestasi Belajar IPS. Jurnal Pendidikan Dasar Nusantara Volume 2 Nomor 2.Write Terhadap Hasil Belajar IPS Terpadu Siswa Kelas VIII Semester Genap SMP PGRI 4 Labuhan Ratu. JPGMI Universitas Nahdatul Ulama Vol.3 No.1. 